\section{Efecto de la}

decolonización

en bacteriuria y

candiduria en UCI.

Effect of body surface

decolonisation

on bacteriuria

and candiduria in

intensive care units:

an analysis of a

cluster-randomised

trial.

Huang SS, Septimus E,

Hayden $M K$,

Kleinman $K$,

Sturtevant J,

Avery $T R$, et al.

Lancet Infect Dis

2016: 16: 70-9.
Introducción: Las infecciones del tracto urinario son las infecciones asociadas a la atención en salud más frecuentes en las unidades de cuidados intensivos. La bacteriuria precede la infección y frecuentemente se trata con antimicrobianos.

Metodología: Se trata de un estudio realizado en 74 UCIs de adultos, en 43 hospitales de E. U. A., entre mayo de 2010 y septiembre de 2011, para conocer el efecto de la decolonización sobre la bacteriuria y candiduria en pacientes que ingresan a UCI. Cada UCI fue asignada a una de las tres ramas del estudio: búsqueda de portación de Staphylococcus aureus resistente a meticilina (SARM) mediante cultivo nasal y aislamiento de contacto; búsqueda de SARM, aislamiento de contacto y decolonización con clorhexidina y mupirocina, y un último grupo con decolonización universal (sin estudio de portación). El protocolo de decolonización utilizado fue: baño con clorhexidina al $2 \%$, una vez al día, por cinco días más mupirocina nasal, dos veces al día, por 5 días en la segunda rama del estudio, y en la tercera rama se mantuvieron los baños con clorhexidina durante toda la estadía en UCI, y el uso de mupirocina tópica, dos veces al día. La indicación de baño con clorhexidina incluía limpieza del periné y los $15 \mathrm{~cm}$ proximales del catéter urinario. Se supervisó en forma trimestral el cumplimiento por parte del personal de cada UCI incluida en el estudio. Los resultados que analizaron fueron: bacteriuria de alto nivel ( $>$ de 50.000 $\mathrm{ufc} / \mathrm{ml}$ ) de cualquier uropatógeno, candiduria de alto nivel ( $>50.000 \mathrm{ufc} / \mathrm{ml}$ ) y cualquier bacteriuria con uropatógenos, por 1.000 días UCI. Se incluyó el primer cultivo por paciente que cumplía el criterio y que fuera atribuible a su estadía en UCI (a partir de $48 \mathrm{~h}$ del ingreso a UTI y hasta $48 \mathrm{~h}$ posterior al egreso). Se comparó la reducción de estos parámetros en cada grupo, durante los 18 meses de la intervención, comparado con los 12 meses previos, utilizados como basal. También se realizó análisis de diferencia por sexo, debido al mayor riesgo de infección urinaria conocido en mujeres, por flora endógena.

Resultados: Se enrolaron 122.646 pacientes (48.390 del período basal y 74.256 del período de intervención). Las características demográficas de los pacientes en los tres grupos fueron similares, así como al comparar entre pacientes del período basal y de intervención. Los riesgos observados para bacteriuria de alto nivel no mostraron diferencias entre los tres grupos de la intervención, ni tampoco por sexo. El riesgo de candiduria de alto nivel fue significativamente menor en el grupo con decolonización universal, el cual obedeció a una mayor reducción observada en el sexo masculino. Lo mismo ocurrió con bacteriuria de cualquier nivel, que fue menor en el grupo de hombres de la rama con decolonización universal. Los autores concluyen que la decolonización universal de pacientes en UCI con baños de clorhexidina diarios puede ser una estrategia de prevención de candiduria y bacteriuria en pacientes de sexo masculino, no así en pacientes de sexo femenino.

Comentario: Este es uno más de los múltiples estudios que se han publicado durante los últimos años, para evaluar la efectividad de realizar baños de clorhexidina en pacientes críticos. Los resultados han sido dispares, y no hay claridad aún respecto de cuál sería la mejor estrategia para realizar estos baños. Sin embargo, cada vez más existe la percepción de que esta práctica se consolida como un estándar de atención en pacientes de unidades críticas, para prevenir la aparición de diversas infecciones asociadas a atención de salud.

Beatrice Hervé
Clínica Las Condes
Comité de Infecciones Asociadas a la Atención de
Salud
Correspondencia a:
bherve@clinicalascondes.l

Clínica Las Condes

Correspondencia a: 